\title{
Presence of Organic Pesticides in Commercial Rainbow Trout Farms
}

\author{
Ana Paula Monschau Funck ${ }^{1}$, José Antônio Beirão Simões ${ }^{1}$, Marina Guimarães Ferreira ${ }^{2}$, Lilian de Paula \\ Gonçalves Reis ${ }^{1}$, Fabiano Aurélio da Silva Oliveira ${ }^{3}$, Luciano dos Santos Rodrigues ${ }^{1}$, Marilia Martins \\ Melo $^{1}$ and Kleber Campos Miranda Filho*1
}

${ }^{1}$ Universidade Federal de Minas Gerais - UFMG, Av Pres Antônio Carlos, Brazil

${ }^{2}$ Universidade Federal de Lavras - UFLA, Av Doutor Sylvio Menicucci, Brazil

${ }^{3}$ Laboratório Nacional Agropecuário, Ministério da Agricultura, Pecuária e Abastecimento, Brazil

Received: February 28, 2018; Published: March 16, 2018

*Corresponding author: Kleber Campos Miranda-Filho, Universidade Federal de Minas Gerais, Escola de Veterinária, Departamento de Zootecnia, Laboratório de Aquacultura - LAQUA, Av. Antônio Carlos, 6627, CEP 31270-901, Belo Horizonte, MG, Brazil, Tel: + 55 31 $3409-3311$;

Email: kleber08@gmail.com

\begin{abstract}
The objective of the present study was to evaluate the presence of pesticides in different matrices, such as: water, fish, soil and feed, during rainbow trout production in a raceway system. During the rainy and dry periods (2014 and 2015), the parameters temperature, $\mathrm{pH}$, dissolved oxygen (OD) and alkalinity were also evaluated. The water matrix residues were extracted by the Luke method and fish, soil and feed matrices were extracted by the modified QuEChERS method. The extracts were evaluated by multi-residue HPLC-MS / MS analysis with limit of detection - LOD (1 ppb) and limit of quantification - LOQ (10 ppb). For the water matrix, residues of organophosphates, carbamates, pyrethroids, anilinopyrimidines, strobirulins and alkyl sulfite were detected in the trout cultures. However, only organ phosphorus insecticides (chlorpyrifos and dichlorvos) were quantified. In trout farm A was detected and quantified chlorpyrifos at $0.019 \mathrm{mg} / \mathrm{L}$ point $\mathrm{A} 1$ and dichlorvos at the concentrations of $0.136 \mathrm{mg} / \mathrm{L}$ point $\mathrm{A} 1$ (tributary) and $0.0465 \mathrm{mg} / \mathrm{L}$ point A6 (effluent)

In trout farm B, dichlorvos were quantified at $0.0209 \mathrm{mg} / \mathrm{L}$ point B1 (tributary) and $0.0578 \mathrm{mg} / \mathrm{L}$ point B9 (tributary). All concentrations of pesticides described were above the Maximum Residue Limit (MRL) recommended by the European Union. For soil and feed matrices there was no detection of pesticide residues for the trout farms. For the fish matrix there was no detection of residues in trout farm A, but there was detection (within the limit of the equipment) of trout farm B in the tissues: gills, liver and kidney. The physicochemical variables evaluated may have provided the pesticides hydrolysis and the rainy season may have influenced the greater amount of residues in the water, but within the limits of detection of the equipment. However, dry period may have influenced the concentration of chlorpyrifos and dichlorvos. The identification of residues in the rainbow trout tissues in trout farm B in October suggests that further studies should be carried out to verify the possibility of bioconcentration in the tissues due to the different classes of pesticides that can be found in the aquatic environment.
\end{abstract}

Keywords: Water quality; Waste; Raceway; Rainbow trout

Abbreviations: OD: Dissolved Oxygen; MEL: Maximum Residue Limit; PSA: Primary-Secondary Amine Sorbent; ESI: Electro-Spray Ionization; ANOVA: Analysis of Variance; LOD: Limit of Detection; MRL: Maximum Residue Limit; EU: European Union; ALP: Alkaline Phosphatase; ACP: Acid Phosphate

\section{Introduction}

Pesticides are used to control various pests, aiming at public health and higher productive rates in agriculture, but generate toxic waste and pollute the environment such as air, water and soil. In addition, they affect non-target organisms such as plants, animals and humans. The presence of pesticide residues in the water is becoming a frequent environmental problem and this occurrence can occur after application by spray drift, surface runoff and leaching Chowdhury et al. [1-4]; The degradation rate of each pesticide will depend on the environmental conditions prevailing in the ecosystem (physicochemical and microbiological characteristics of the water) [5,6] and the physicochemical properties of the pesticide [7]. The presence of pesticides in water can cause damage to aquatic organisms $[8,9]$, including those for aquaculture production. 
According to Greco et al. [10], these damages may reflect the survival and/or zoo technical performance of the organisms kept in captivity, based on acute or chronic intoxication, respectively. According to some authors [5,9], non-degraded pesticide residues can accumulate in the body (adipose tissue) and undergo biomagnifications along the trophic chain. This fact is likely to occur, since the pesticides present in the water may undergo bioconcentration in several organs, including gills, liver and muscle Akan et al. [11]; Oliveira et al. [12]. In addition, as described earlier, pesticides can cause human health problems [13], due to food contamination $[1,4]$.

In this sense, due to the increase in the production and consumption of rainbow trout Oncorhynchus mykiss in Brazil, it should be noted that despite high daily water renewal, normally used in the raceway system, changes in the water quality of trout farms can occur due to the high stocking density, high feed rates, rainy periods and also the increase of the agricultural areas close to the fish production systems. Considering that for aquaculture production the improvement of productivity may depend directly on water quality, food management and environmental conditions, it is important to evaluate the presence of pesticides in water, inputs, soil and farmed animals. The objective of the present study was to evaluate the presence of pesticides in different matrices, such as: water, fish, soil and feed during rainbow trout production in a raceway system.

\section{Material and Methods}

Table 1: Characteristics of commercial trout farms A and B in raceway system.

\begin{tabular}{|c|c|c|}
\hline Features & Trout farm A & Trout farm B \\
\hline Water source & River & Stream \\
\hline Species & O. mykiss & O. mykiss \\
\hline Main activity & Grow out & Reproduction \\
\hline Production & $120,000 \mathrm{Kg} / \mathrm{year}$ & $\begin{array}{c}120-150,000 \\
\text { juveniles } / \text { year }\end{array}$ \\
\hline Mean of stocked fish & $26,000 \mathrm{Kg} /$ month & $\begin{array}{c}1,350 \mathrm{Kg} / \text { month } \\
\text { (breeding) }\end{array}$ \\
\hline Final weight & $300-500 \mathrm{~g}$ & - \\
\hline Feed consumption per day & $625 \mathrm{Kg}$ & $30 \mathrm{Kg}$ \\
\hline Total tanks and volume & 23 tanks $\left( \pm 65 \mathrm{~m}{ }^{3}\right.$ ) & 6 tanks $\left( \pm 7 \mathrm{~m}{ }^{3}\right)$ \\
\hline Daily water volume & $86,227 \mathrm{~m}^{3}$ & $1,469 \mathrm{~m}^{3}$ \\
\hline Total turnover & 58 times a day & 35 times a day \\
\hline Average flow (period) & $1,047.42 \mathrm{~L} / \mathrm{s}$ & $17.66 \mathrm{~L} / \mathrm{s}$ \\
\hline Handling & Manual & Manual \\
\hline
\end{tabular}

Rainbow Trout Farms Location: The experiment was carried out in two commercial rainbow trout farms named A and B, located in Brazil with an average altitude of $1260 \mathrm{~m}$. The cultivation system used for the production of the species 0 . mykiss was continuous stream or raceway. This Brazilian region meets ideal climatic conditions, such as low temperatures, rugged relief and excellent water quality, making this area, one of the largest producers of trout in Brazil. Trout farm B, although specialized in the production of juveniles, maintains a stock of fish for grows out and as "fish and pay". Other characteristics are shown in Table 1.

Agricultural Characterization of Rainbow Trout Culture Area: In the agricultural context, areas close to the trout farms, besides highlighting trout production, develop their activities aimed to family agriculture, such as the production of cattle, for milk production, equines (small size) and also products such as vegetables, potato and corn crops, in addition to eucalyptus (reforestation). However, it was already a region where some factories were set up in 1924 to exploit fruit production such as quince and pear Faria et al. [14].

Collection of Samples: In the two rainbow trout farms monthly collections were carried out during the years 2014 and 2015, to monitor water physicochemical characteristics and pesticides residues. Two points were chosen: trout farm A (A1-affluent and A6-downstream) (Figure 1) and trout farm 2 (B1-affluent and B9downstream) (Figure 2). For pesticide residue assessments, thirtytwo water samples were collected in each trout farm, of which twenty-four samples were collected in 2014 and eight samples were collected in 2015. The samples were taken from: in trout farm A in A1 (affluent) and A6 (downstream), and in trunculture B, in B1 (affluent) and B9 (downstream), all samples were collected in sterile polypropylene flasks with a capacity of $200 \mathrm{~mL}$ and frozen. In order to transport the samples, they were stored in a polystyrene box with ice and then kept frozen at $-20^{\circ} \mathrm{C}$ in the freezer until its processing. For the study of the biological material, thirty-six samples of rainbow trout with average weight between $450 \mathrm{~g}$ and $\pm 35 \mathrm{~cm}$ in length were monthly collected in each fish farm. During 2014, samples were collected in December and January and in 2015 in January, February, July and August with a total of six samples per month in each rainbow trout farm.

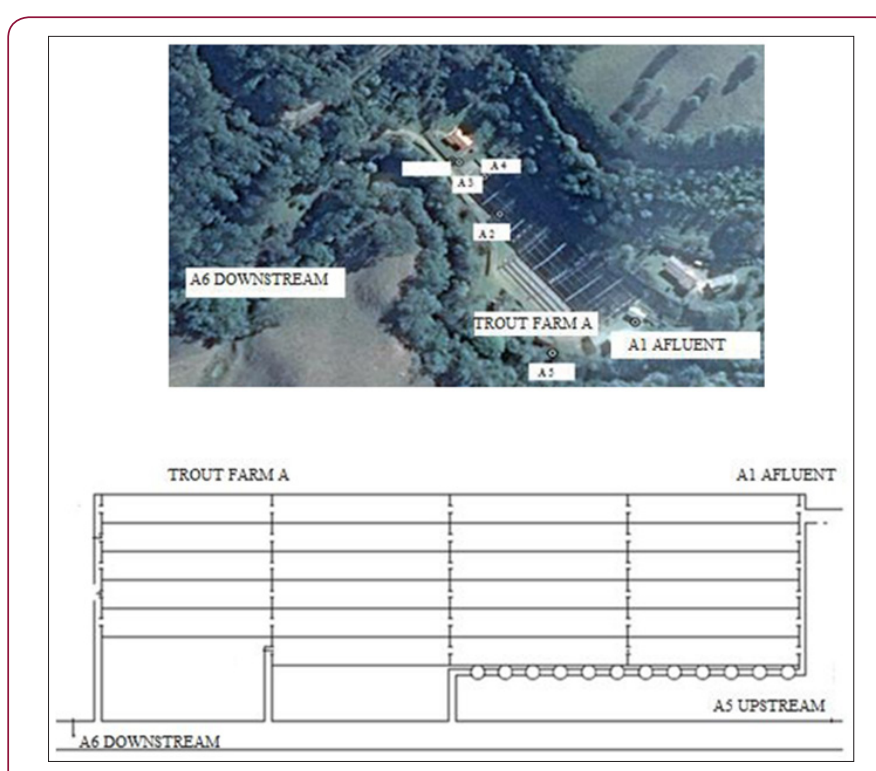

Figure 1: Images of the collection points (A1 and A6) in the trout farm $\mathrm{A}$. 

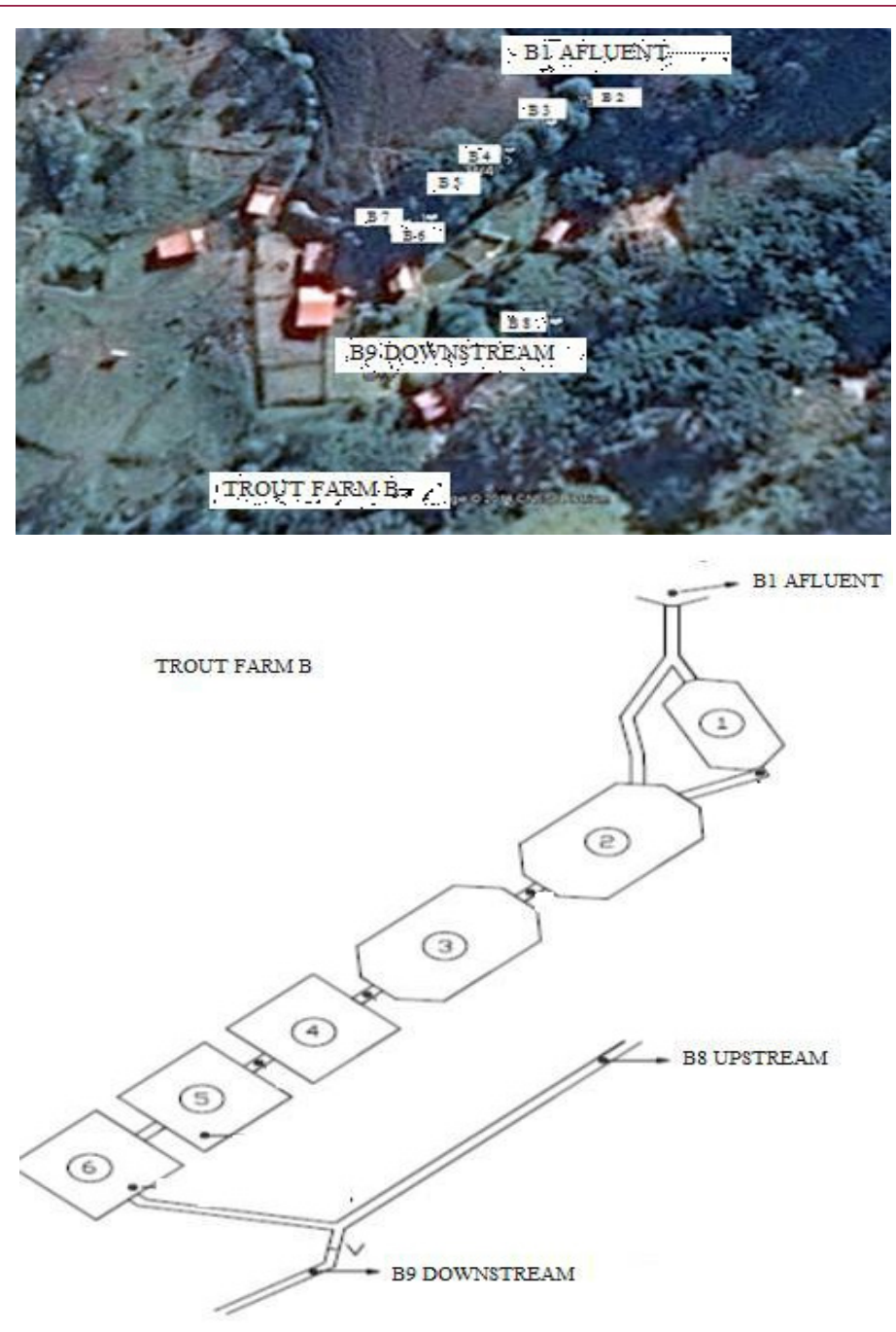

Figure 2: Images of the collection points (B1 to B9) in the trout farm B.

The fish were desensitized in melting ice by hypothermia and samples of muscle, gills and liver were collected, which after collection were wrapped in aluminum foil, identified, frozen and stored in a freezer at $-20^{\circ} \mathrm{C}$ for laboratory analysis. For soil study (during 2014), twelve samples were collected at two points marked in farm A, A7 (upstream) and A8 (downstream) and farm B, B11 (upstream) and B12 (downstream) also twelve samples. The samples were collected (until $20 \mathrm{~cm}$ deep), duly identified, stored in foil, plastic bag and then frozen and stored in a freezer at $-20^{\circ} \mathrm{C}$. For quality of the diet (commercial feed) study, six samples of three commercial brands were collected in farm A and six samples of two commercial brands in farm B in 2014. About $100 \mathrm{~g}$ of each sample were stored in polypropylene bag, wrapped in foil, identified and frozen.

Methodology for Physicochemical Analysis of Water: Temperature and $\mathrm{pH}$ data were taken in situ using a portable pH meter (PH-221 Lutron). Analyses of dissolved oxygen (OD) (analysis 4500) and alkalinity (analysis $2320 \mathrm{~B}$ ) were carried out in laboratory from water samples collected in sterile $200 \mathrm{~mL}$ bottles, according to Standard Methods Water and Wastewater (APHA, 2008) [15].

Method of Extraction of Pesticides in Water, Fish, Soil, and Feed (Commercial Ration): To evaluate the presence of pesticide residues in the two commercial farms, in the water matrix, an adaptation of the Luke et al. [16] method was used because it can identify polar and a polar pesticides. For the other matrices, biota (trout), soil and feed, the modified Quick Easy Cheap Effective Rugged Safe (QuEChERS) method was used [17]. It can provide the best sample/extract ratio $1 \mathrm{~g}$ per $1 \mathrm{~mL}$ of solvent and may provide better extraction quality of the analytes from the matrices evaluated.

Analytical Run - Water Matrix Extraction: To extract the analytes from the water matrix, $100 \mathrm{~mL}$ of sample was used with the addition of $200 \mathrm{~mL}$ of chloroform. Afterwards, samples were shaken in a glass flask $500 \mathrm{~mL}$, where the formed gas was released gradually and soon after the separation took place in two phases (water and solvent). Then the sample was filtered with $20 \mathrm{~g}$ of sodium sulfate PA and collected in glass beaker $(50 \mathrm{~mL})$, where 
after evaporation the vessel was washed with $1 \mathrm{~mL}$ of chloroform $\mathrm{PA}$ and stored in a vial and frozen at $-20^{\circ} \mathrm{C}$.

Analytical run - Extraction for Muscle, Gills, Liver, Soil and Ration: Each sample (muscle, gill, liver) was weighed (5 g) and stored in Falcon tube $(50 \mathrm{~mL}), 5 \mathrm{~mL}$ deionized water added and homogenized in Ultra Turrax for 15 seconds. Then compounds used as solvents, $7 \mathrm{~mL}$ of $\mathrm{CH} 3 \mathrm{CN}$ (acetonitrile) and $3 \mathrm{~mL}$ of EtOAc C4H8O2 (ethyl acetate), were vortexed for $1 \mathrm{~min}$. After this step 4 $\mathrm{g}$ of MgSO4 (magnesium sulfate) was added with $1 \mathrm{~g}$ of $\mathrm{CH} 3 \mathrm{COONa}$ (sodium acetate) to promote the partitioning process, then vortexed again for $1 \mathrm{~min}$ and centrifuged for $11 \mathrm{~min}$ at $4000 \mathrm{rpm}$. After these procedures, the sample was frozen for a period of $12 \mathrm{~h}$ at $-20^{\circ} \mathrm{C}$. The next day, the sample was thawed and centrifuged for 5 min at $4000 \mathrm{rpm}$ at a temperature of $-5^{\circ} \mathrm{C}$. For clean up, supernatant was collected ( $1 \mathrm{~mL}$ ) and transferred to a vial containing $150 \mathrm{mg}$ of MgSO4, $3 \mathrm{mg}$ of the primary-secondary amine sorbent (PSA), $3 \mathrm{mg}$ octadecyl (C 18), and vortexed for $1 \mathrm{~min}$. and then centrifuged for $12 \mathrm{~min}$. at $9000 \mathrm{rpm}$. The extract $(1 \mathrm{~mL})$ was transferred to a vial and frozen at $-20^{\circ} \mathrm{C}$. For soil samples the same extraction method was used, but due to the absence of fat it was not necessary to add PSA and C18 together with the final step. For feed samples, moisture content was calculated for correction and it was necessary to raise the moisture content of the matrix equal to or greater than $80 \%$, before the extraction method.

ChromatographicMethod,EquipmentandChromatographic Conditions: The pesticides selected for this study are listed in Annex 1. All of them were evaluated using the multiresidues technique and all the extracts $(1 \mathrm{~mL})$ were injected and analyzed by Liquid Chromatography coupled to Mass Spectrometry (LC-MS / MS). The chromatograph used was Shimadzu (Kyoto, Japan), composed by: two binary pumps model LC20ADXR; automatic injector model SIL20ACXR; model column furnace; and the MS detector, TRIPLE QUAD 5500 (Applied Biosystems, MDS SCIEX, and Ontario, Canada) with electrospray ionization source (ESI), with detection limit of $1 \mathrm{ppb}$ and quantification of $10 \mathrm{ppb}$. The instrument was operated under electrospray ionization (ESI) conditions in both positive and negative ion modes. Instrument configurations, data acquisition and processing were controlled by Analyst software (Version 1.5.1,

Table 2: Means ( \pm standard deviation) of the physiochemical parameters ( $\mathrm{pH}$, temperature, dissolved oxygen and alkalinity) evaluated on collection points (A1, A6, B1, B9) during rainbow trout cultivation in raceway in periods of rain and drought (2014 and 2015) in two commercial trout farms (A and B).

\begin{tabular}{|c|c|c|c|c|c|c|c|c|}
\hline \multirow{2}{*}{ Param. } & \multicolumn{4}{|c|}{ Trout farm A } & \multicolumn{4}{c|}{ Trout farm B } \\
\cline { 2 - 9 } & Point A1 (affluent) & Point A6 (downstream) & \multicolumn{2}{c|}{ Point B1 (affluent) } & \multicolumn{2}{c|}{ Point B9 (downstream) } \\
\cline { 2 - 9 } & Rain & Drought & Rain & Drought & Rain & Drought & Rain & Drought \\
\hline Alc. & $20.91 \pm 5.23$ & $18.57 \pm 1.90$ & $22.00 \pm 5.47$ & $20.42 \pm 5.15$ & $29.25 \pm 2.98$ & $26.14 \pm 7.47$ & $36.75 \pm 4.75$ & $34.85 \pm 6.56$ \\
\hline OD & $7.61 \pm 1.15$ & $7.64 \pm 1.72$ & $7.37 \pm 1.19$ & $7.88 \pm 2.05$ & $7.37 \pm 1.19$ & $7.50 \pm 1.19$ & $7.17 \pm 0.96$ & $7.22 \pm 2.20$ \\
\hline pH & $7.50 \pm 0.85$ & $7.71 \pm 0.62$ & $7.38 \pm 0.50$ & $7.43 \pm 0.75$ & $7.57 \pm 0.74$ & $7.67 \pm 0.37$ & $7.39 \pm 0.35$ & $7.30 \pm 0.22$ \\
\hline Temp. & $17.35 \pm 1.3 \mathrm{a}$ & $13.68 \pm 2.2 \mathrm{~b}$ & $17.44 \pm 1.23 \mathrm{a}$ & $13.8 \pm 1.96 \mathrm{~b}$ & $17.38 \pm 1.00 \mathrm{a}$ & $14.64 \pm 1.57 \mathrm{~b}$ & $18.53 \pm 1.07 \mathrm{a}$ & $15.05 \pm 2.23 \mathrm{~b}$ \\
\hline
\end{tabular}

Alk.: Alkalinity; O.D: dissolved oxygen; Param.: parameter; Temp .: Temperature. Means followed by lower case letters in the row differ from each other at $5 \%$ significance by the Tukey test.

Some pesticides may be more recalcitrant to hydrolysis at $\mathrm{pH} 7$, such as carbamate aldicarb (189 days), pyrethroids cypermethrin
Applied Biosystems). The optimized source parameters of the pesticides were: ionic spray voltage, $5.5 \mathrm{kV}$ for ESI (+) and $4.5 \mathrm{kV}$ for ESI (-); Gas curtain, 20 psi; Collision gas, 8 psi; Nebulizer and auxiliary gas, $30 \mathrm{psi}$; Ion source temperature $=500^{\circ} \mathrm{C}$.

\section{Statistical Analysis}

Descriptive statistical analysis was used for the results concerning water, soil, feed (ration) and fish. All analyses were submitted to evaluation of the normality of errors (Cramervon Mises), homoscedasticity of variance (Levene's), analysis of variance (ANOVA) and subsequently Tukey test (5\% probability).

\section{Results and Discussion}

\section{Physicochemical Characteristics of Water During Rainbow Trout Culture}

The pesticide degradation can be related to various aspects of water quality, as well as physicochemical and microbiological factors. In this sense, water quality was monitored, since most of pesticide formulations were developed for dilution at $\mathrm{pH} 7$ to allow greater action on target organisms. Only significant differences $(p<0.05)$ were observed between rainfall and dry season for temperature distinguishes these two periods in study. However, physicochemical parameters, such as $\mathrm{pH}$, temperature, dissolved oxygen and alkalinity, may influence the rate of pesticide degradation (Table 2). These parameters can degrade Organophosphorus pesticides, carbamates Zamy et al. [18]; Hui et al. [5] and pyrethroids [19] in the aquatic environment. Due to the influence of alkalinity on the average values of $\mathrm{pH}$ and considering the results of this study in the two trout farms, it is verified the tendency of alkaline $\mathrm{pH}$, as a factor that can influence the degradation of some pesticides due to the more pronounced hydrolysis. According to Zamy et al. [18], hydrolysis can be more effective at $\mathrm{pH}$ between 8-9 and its rate can increase by 10 times. For example, among Organophosphorus compounds quantified in the cited study, chlorpyrifos degraded at $20^{\circ} \mathrm{C}$ at pH 5 in 68 days, pH 7 in 25.5 days and pH 8 in 23 days, and dichlorvos was degraded at $\mathrm{pH} 7$ and temperature at $-20^{\circ} \mathrm{C}$ in 4.7 days. parameter due to the characteristic thermal amplitude that 
salinity also influence the degradation time of the pesticides. In the present study, temperature was below the optimum degradation range, $-25^{\circ} \mathrm{C}(\mathrm{PPDB}, 2009)$ [19]. In this sense, the degradation of Organophosphorus chlorpyrifos (in freshwater at $10^{\circ} \mathrm{C}$ ) occurred in 18.7 days, while in sea water $\left(10^{\circ} \mathrm{C}\right)$, it suffered degradation up to 49.4 days (Bondarenko et al., 2004) [13]. For some organophosphates, temperature may influence their degradation as occurred for diazinone at $\mathrm{pH} 7.3$ which at $6^{\circ} \mathrm{C}$ degradation

Table 3: Residues of pesticides found in the water samples in the trout farms A and B during the rainy and dry seasons (2014 and 2015).

\begin{tabular}{|c|c|c|c|c|c|c|}
\hline & \multicolumn{2}{|c|}{ Trout farmA } & & \multicolumn{2}{|c|}{ Trout farmB } & \\
\hline & \multicolumn{2}{|c|}{ Collection points } & & \multicolumn{2}{|c|}{ Collection points } & \\
\hline & A1(Aff.) & A6(Dow.) & & B1(Aff.) & B9(Dow.) & \\
\hline Pesticide & \multicolumn{2}{|c|}{ Concentration mg/L } & & \multicolumn{2}{|c|}{ Concentration mg/L } & Season \\
\hline \multicolumn{7}{|l|}{ Organophosphorus } \\
\hline Chlorpyrifos & 0.019 & - & Drought & - & - & - \\
\hline Dichlorvos & 0.136 & 0.0465 & Drought & 0.0209 & 0.0578 & Drought \\
\hline Diazinone & - & $\mathrm{LOD}<\mathrm{C}<\mathrm{LOQ}$ & Rain & $\mathrm{LOD}<\mathrm{C}<\mathrm{LOQ}$ & $\mathrm{LOD}<\mathrm{C}<\mathrm{LOQ}$ & Rain \\
\hline Ethion & - & $\mathrm{LOD}<\mathrm{C}<\mathrm{LOQ}$ & Rain & - & - & - \\
\hline Phosalone & - & $\mathrm{LOD}<\mathrm{C}<\mathrm{LOQ}$ & Drought & - & - & - \\
\hline Parathion ethyl & - & $\mathrm{LOD}<\mathrm{C}<\mathrm{LOQ}$ & Rain & - & $\mathrm{LOD}<\mathrm{C}<\mathrm{LOQ}$ & Rain \\
\hline Paraoxon ethyl & - & $\mathrm{LOD}<\mathrm{C}<\mathrm{LOQ}$ & Rain & - & $\mathrm{LOD}<\mathrm{C}<\mathrm{LOQ}$ & Rain \\
\hline Pirimiphos methyl & - & - & - & - & $\mathrm{LOD}<\mathrm{C}<\mathrm{LOQ}$ & Drought \\
\hline \multicolumn{7}{|l|}{ Carbamate } \\
\hline Aldicarb & - & - & - & - & $\mathrm{LOD}<\mathrm{C}<\mathrm{LOQ}$ & Rain \\
\hline Ald. sulfoxide & - & - & - & - & $\mathrm{LOD}<\mathrm{C}<\mathrm{LOQ}$ & Drought \\
\hline Carbaryl & & $\mathrm{LOD}<\mathrm{C}<\mathrm{LOQ}$ & Drought & - & $\mathrm{LOD}<\mathrm{C}<\mathrm{LOQ}$ & Drought \\
\hline Carbofuran & - & - & - & - & $\mathrm{LOD}<\mathrm{C}<\mathrm{LOQ}$ & Drought \\
\hline \multicolumn{7}{|l|}{ Pyrethroid } \\
\hline Cypermethrin & & $\mathrm{LOD}<\mathrm{C}<\mathrm{LOQ}$ & Rain & - & - & - \\
\hline Deltamethrin & $\mathrm{LOD}<\mathrm{C}<\mathrm{LOQ}$ & - & Drough & - & - & - \\
\hline \multicolumn{7}{|l|}{ Anilinopyrimidine } \\
\hline Cyprodinil & - & $\mathrm{LOD}<\mathrm{C}<\mathrm{LOQ}$ & Rain & $\mathrm{LOD}<\mathrm{C}<\mathrm{LOQ}$ & $\mathrm{LOD}<\mathrm{C}<\mathrm{LOQ}$ & Rain \\
\hline \multicolumn{7}{|l|}{ Strobirulin } \\
\hline Trifloxystrobin & - & $\mathrm{LOD}<\mathrm{C}<\mathrm{LOQ}$ & Rain & - & - & - \\
\hline \multicolumn{7}{|l|}{ Alkyl sulphite } \\
\hline Propargite & - & $\mathrm{LOD}<\mathrm{C}<\mathrm{LOQ}$ & Rain & - & $\mathrm{LOD}<\mathrm{C}<\mathrm{LOQ}$ & Rain \\
\hline
\end{tabular}

Aff.: Affluent; Dow.: downstream; Ald.: aldicarb; LOD $<\mathrm{C}<\mathrm{LOQ}$ indicates that the residue was detected. but not quantified.

\section{Toxicological Evaluations of Water}

In this study, fifteen different types of pesticides and two types of metabolites were identified for the water matrix. In the farm A, twelve types of pesticides were detected with one type of metabolite and in farm B, eight types of pesticides and two types of metabolites during the rainy and dry periods of 2014 and 2015, with a greater variety of residues during rainy periods (Table 3). Most concentrations found in the water were within the limit of detection (LOD) of equipment (1 ppb), but not higher than the limit may occur between $132-181$ days, but at $22^{\circ} \mathrm{C}$ the half-life may range from 50-80 days. In the same $\mathrm{pH}$ as mentioned, for carbaryl (carbamate) the half-life may be 45 days at $6^{\circ} \mathrm{C}$ and for 2 days, if the temperature $=22^{\circ} \mathrm{C}[20]$. Increases in dissolved oxygen in water can influence the microbiological degradation of pesticides, such as pyrethroids at $\mathrm{pH}(7.3-8.8)$, temperature $\left(28-30^{\circ} \mathrm{C}\right)$ and dissolved oxygen between $8-9 \mathrm{mg} / \mathrm{L}$, degradation rate is rapid after $48 \mathrm{~h}$ [19]. 
samples with pesticide residues and farm B with eight samples (25\%).

The most frequent class of residues was organophosphates, such as chlorpyrifos, dichlorvos, diazinone, ethion, phosalone, ethyl paration, paraoxon ethyl (ethyl paration) and pirimiphos methyl; carbamates such as aldicarb, aldicarb sulfoxide (aldicarb metabolite), carbaryl and carbofuran; pyrethroids such as cypermethrin and deltamethrin, mostly used as insecticides, but were also found residues of other classes such as anilinopyrimidine (cyprodinil), strobirulin (Trifloxystrobin) and alkyl sulfite (propargite) (Table 3). Of the thirty-six samples of the biota matrix (trout) collected in each farm during 2014 and 2015, there was no residue detection in farm A, only in farm B. For the year 2014 (in October), residues of pyrethroids (bifenthrin) and carbamates (desmedipham and furatiocarb) were detected but not quantified, however in the other months there was no detection. For the twenty-four soil samples and twelve feed samples evaluated in the two farms, there was no detection of pesticide residues.

There was a difference between types of pesticides detected in the rainy and dry season with concentrations above LOD (10 $\mathrm{ppb}$ ) that occurred during the dry period for the organophosphates chlorpyrifos and dichlorvos. However, both periods showed the detection of pesticides in the water demonstrating that their contamination can occur for more than one season and this fact was demonstrated by Veiga et al. [21] when detecting organophosphates and carbamates in $70 \%$ of the samples surveyed in surface and groundwater. In addition, insecticides have been found to be toxic in rivers, lakes and lagoons [22] and may affect several aquatic organisms, such as fish [9]. Pesticides can reach the water through surface runoff and leaching Ara et al. [3] and aerial currents [1].

However, climatic conditions at the time of application, such as air temperature and humidity, can affect the chemical volatility of the pesticide [6], leading to its degradation. Organophosphate pesticides are the most widely used insecticides and can be employed as herbicides and fungicides. Most organophosphate insecticides are inhibitors of acetyl cholinesterase (AChE), which is one of the most important enzymes in nerve impulse transmission [23]. In addition to the toxic potential for 301 animals and humans, by the inhibition of AChE [12], organophosphates, besides being neurotoxin, are also considered endocrine disrupters, 9 with anti-androgenic, estrogenic properties, and can be mutagenic, carcinogenic, and responsible for causing respiratory and cutaneous allergies (PPDB, 2009). Chlorpyrifos was detected in farm an in three samples $(9.37 \%)$, one sample $(3.12 \%)$ in the tributary (A1), in the rainy period and in one sample $(3.12 \%)$ downstream (A6) in the dry season of 2014 .

In the same year in farm $\mathrm{B}$, the same was detected in 5 samples (15.6\%), of these, two samples (6.25\%) in the affluent (B1) and One sample (3.12\%) downstream (B9), both in the rainy season and in two samples (6.25\%) in the dry season. Class II (moderately hazardous), non-systemic toxicity, but may be very toxic if ingested and considered highly toxic to fish and birds (PPDB, 2009). The maximum residue limit (MRL) for chlorpyrifos in water samples by the European Union (EU) is $0.01 \mathrm{mg} / \mathrm{L}$ [24] and in farm A was detected and quantified at a concentration of $0.019 \mathrm{mg} / \mathrm{L}$ in the affluent (A1), drought period (April), being slightly above the allowed MRL. In comparison to the present work, [24] found chlorpyrifos concentrations in the Challawa River (Nigeria) from 0.35 to $0.78 \mathrm{mg} / \mathrm{L}$, above what is allowed by the European Union. The pollution of the Nigerian 319 river occurs by receiving industrial waste and agricultural runoff.

In Brazil, contamination of the aquatic environment with chlorpyrifos may be related to its use as acaricide in bovine herds, where it can be associated with other active principles such as dichlorvos and cypermethrin to combat tick Riphicephalus micropulus $[25,26]$. Such chlorpyrifos contamination may compromise normal liver function of tilapia juveniles by causing hepatocyte injury [27] and provoke hypocalcemia in catfish Heteropneustes fossilis and cause prolactin hyperactivity, however hypocalcemia may trigger physiological changes with effects on sperm motility and reproduction [28]. The insecticide dichlorvos was detected in two samples (6.25\%) in farms A and B, during the dry season of 2014. In farm A, in the affluent (A1), dichlorvos was quantified in April in one sample $(3.12 \%)$, with a concentration of $0.136 \mathrm{mg} / \mathrm{L}$; and in one sample (3.12\%), downstream (A6), with $0.046 .5 \mathrm{mg} / \mathrm{L}$, in May.

In farm B, dichlorvos were detected in the affluent (B1) in a sample (3.12\%), quantified at $0.020,9 \mathrm{mg} / \mathrm{L}$ and downstream site (B9) in one sample (3.12\%), quantified in $0.057 .8 \mathrm{mg} / \mathrm{L}$, in June. Note that the night before the day of collection there was heavy rain that may have led to the transport of waste from the surroundings of the farm to the water. The concentrations of dichlorvos in the two crops were above the permitted MRL $(0.004 \mathrm{mg} / \mathrm{L})$ by the EU. Other authors have also found concentrations of dichlorvos above what is permitted. [24] reported that levels of 0.16 to $0.54 \mathrm{mg} / \mathrm{L}$ of dichlorvos in the waters of the Challawa River (Nigeria) would be associated with pollution caused by industries and agricultural activity. Dichlorvos has a Class Ib toxicity (highly hazardous), high aqueous solubility, volatility and low bioconcentration factor (PPDB, 2009). After its application, it is extremely dangerous if inhaled, absorbed or ingested [29].

The pesticide has been used as a household cleaning agent, which can lead to greater contact between humans and animals. Das et al. [30] described that it can also be employed in commercial salmon to eradicate ectoparasites, such as sea lice Lepophtheirus caligus elogatus. Although it is used in salmon farming, it presents high toxicity to aquatic organisms such as fish, as it can affect metabolism and lead to death [12]. In rainbow trout 0 . mykiss can promote changes in hematological parameters such as leukocyte numbers and hemoglobin levels, compromising the body's defense barrier and oxygen transport respectively [31]. Among the effects associated with the inhibition of AChE by dichlorvos intoxication in fish; Günde and Yerli [32] highlighted the change in behavior with loss of balance with changes in swimming patterns and changes in opercular beating in Poeciliidae Poecilia reticulate and carps Cyprinus carpio. 
In addition to the same changes reported for $P$. reticulate and C. carpio, there were excess mucus production and animal lethality [33]. Diazinone was detected in farm A in two (6.25\%) samples (in 2014) in the downstream rainy season (A6), but in farm B (in 2014), it was detected in three samples (9.37\%), in the rainfall: in two samples (6.25\%) in the affluent (B1) and in a sample (3.12\%) downstream (B9). Diazinone is a Class II (moderately hazardous) insecticide of general use [34], but moderately soluble in water, volatile, with low risk of leaching to groundwater (PPDB, 2009), however it may contaminate surface water due to agricultural activity [2,11]. Its degradation may be faster in freshwater than in seawater [13]. This insecticide is relatively toxic to mammals, but highly toxic to aquatic organisms such as trout, in which it can produce damage to liver cells and promote oxidative stress [35].

In other species such as the striped snakehead fish Channa striata, it can inhibit AChE and reduce growth [36] and in Clarias gariepinus catfish, it can affect the balance, lead to depigmentation, difficulty breathing and death [37]. The insecticide ethion was only detected in the farm A, in one sample (3.12\%) downstream (A6), during the rainy season (in 2014). This insecticide belongs to Class II (moderately dangerous), is non-systemic, with predominant contact action, being volatile and with low aqueous solubility (PPDB, 2009). It has agricultural use with foliar application in pineapple, cotton and citrus, but also can be applied in lawns. Neto and Toledo-Pinto [25] reported that ethion when associated with other active principles such as cypermethrin (pyrethroids) can control ticks in cattle. In mammals, poisoning with ethion can cause oxidative stress by promoting increased lipid per oxidation and alteration of the liver's antioxidant enzymes [38].

Another insecticide detected was phosalone but only in farm A, in one sample (3.12\%), in the downstream drought period (A6), in 2014, and was not detected in farm B. Phosalone is a Class II (moderately hazardous) insecticide, with low water solubility (PPDB, 2009), non-systemic, used to replace DDT in agriculture and to control domestic pests [39], is also used as a household cleaning agent and in gardening. Phosalone is toxic to fish and other aquatic organisms [40]. Reported that phosalone intoxication in common carp C. carpio can cause histopathological changes and among them in the gills (lamellar aneurysm, lamellar fusion and hyperplasia), liver (hypertrophy and nuclear degeneration) and kidney (hypertrophy, degeneration of tubules and dilation of the gromerular capillaries). Organophosphorus ethyl paration and its metabolite, paraoxon ethyl, were detected in the two farms in one sample $(3.12 \%)$ in the rainy period downstream at points (A6 and B9) in 2014.

These chemical compounds are Class I a (extremely dangerous), have broad spectrum action, low aqueous solubility, being persistent with hydrolysis in 260 days (PPDB, 2009). Ethyl parathion can be degraded by the action of humic acids but is very resistant to hydrolysis. At low concentration (e.g. $10 \mathrm{mg} / \mathrm{L}$ ) and pH 5.5, it can form its metabolite paraoxon, and photochemical degradation of paraoxon is faster than hydrolysis or biological degradation [41]. Oliveira et al. [12] searching for pesticides in the viscera and muscle of "curimbatá" Prochilodus costatus, captured in the São Francisco River (Brazil), detected the presence of chlorpyrifos, dichlorvos, diazinone, ethion and phosalone. It was postulated that river pollution was related to agricultural, industrial and urban areas. The authors warned that this species posed a risk to human health, because in that region fish were consumed (contaminated) by riparians and/or distributed in local commerce.

From water samples evaluated during 2015, Organophosphorus was not detected in the farm A, but the pyrimiphos-methyl pesticide was detected in farm B in one sample (3.12\%) in the drought period, downstream (B9). According to PPDB (2009), pirimiphosmethyl belongs to Class II (moderately dangerous) with nonsystemic action, is used to control mosquito larvae [42]. In addition to insect control, it can be used to control mites. Its residues can be found dissolved in water, suspended particles and sediment [43]. Foods can also be contaminated, including corn and popcorn, as the pesticide is used to protect corn grains from insect attacks. In water it may be toxic to fish, such as $P$. reticulata because it causes changes in intestinal cells characterized by degeneration of cell membranes [42], and behavioral changes have also been reported for this species such as lack of balance, erratic swimming and agitation [44].

In addition to organophosphates, carbamates were also detected. Carbamates have high insecticidal activity, moderate degradation capacity and bioaccumulation [12]. They inhibit AChE and some compounds have lower toxic potential for mammals, however, they can be considered as endocrine disrupters, since they affect animal reproduction (PPDB, 2009). According to Altinok et al. [8], carbamates can demonstrate toxic effects to rainbow trout, mainly in gills such as lamellar edema, epidermal separation and lamellar fusion. The insecticide aldicarbe was not detected in farm A but in farm B was detected in two samples (6.25\%) downstream (B9) in the rainy season (in 2014) and its metabolite aldicarb sulfoxide was detected in one sample (3.12\%), in the dry period downstream (B9) (in 2015). Carbamate belongs to Class I a (extremely dangerous), has high aqueous solubility, systemic action, and is extremely toxic and harmful to human health being AChE inhibitor. Aldicarb can form the metabolite aldicarb sulfoxide by Sulfoxidation, which is more toxic with higher level of AChE inhibition [45], Aldicarb, is one of the active ingredients with the highest acute toxicity to mammals. Considered an endocrine disruptor and neurotoxin (PPDB, 2009), it causes damage to cell membranes and may inhibit protein synthesis [46].

It may be moderately toxic to fish such as rainbow trout $O$. mykiss, with effects on inhibition of muscular AChE [45] and highly toxic to birds and bees (PPDB, 2009). In the farm A, carbaryl was detected in two samples (6.35\%), during the dry period at point A6 and in farm B in a sample (3.12\%), during the dry season at points (B9), in 2014. This carbamate has an insecticidal action, belongs to Class II (moderately dangerous), has low aqueous solubility, is volatile and non-persistent in soil or water (hydrolysis of 12 days), highly toxic for mammals, endocrine disruptor and therefore can cause damage on animal reproduction (PPDB, 2009). 
Their residues may contaminate the aquatic environment [13], for use in growing rice, vegetables [1], apple, pineapple and banana. Pollution of the aquatic environment may intoxicate rainbow trout O. mykiss and, in these fish, may decrease enzymatic activity (e.g. catalase and glutathione s-Transferase) and cause oxidative stress [47]. Carbofuran was not detected in farm A but was detected in two samples $(6.25 \%)$ in farm $B$, in the rainy season, downstream (B9), in 2014. According to PPDB (2009), it is a broad-spectrum carbamate insecticide, belonging to Class Ib (highly toxic), sparingly soluble in water, high leaching potential. It has a high toxicity to mammals, being moderately toxic to aquatic organisms and with low potential for bioaccumulation but may act as an inhibitor of AChE and cause changes in the gills, liver, kidney and muscle tissues [48]. High levels $(0.105 \mathrm{mg} / \mathrm{L})$ of carbofuran, related to the residues generated by rice and vegetable crops in Bangladesh [1], above that allowed by the $\mathrm{EU}=0.001 \mathrm{mg} / \mathrm{L}$.

In a study conducted by Begum [48], the acute exposure of catfish Clarias batrachus to carbofuran caused enzymatic damage and may have effects on the metabolism of gills, liver and muscle tissues. When carbofuran is used for the formulation of commercial compounds, it may also be toxic to fish that may present alterations in hematological parameters, such as elevation of plasma glucose due to disruption of carbohydrate metabolism and decrease in plasma protein due to disorders that occur in the liver cells (Ramesh et al., 2015) [49]. Residues of pyrethroids insecticides were found in one sample (3.12\%) in the two farms in 2014 but were not detected in the samples collected in 2015. Pyrethroids are broad spectrum insecticides used in agriculture, households and veterinary medicine. In animals, pyrethroids disturb the function of peripheral nervous system and react with sodium channels affecting their sensitivity in the neurons membrane [50]. Pyrethroids can affect motor coordination, cause convulsion and paralysis [24]. In the aquatic environment, they are highly toxic to fish and invertebrates (PPDB, 2009).

The insecticide cypermethrin was only found in farm A (2014), in one sample (3.12\%), in the rainy period, downstream. It belongs to Class II (moderately dangerous) and has a systemic action, low aqueous solubility, being volatile, highly toxic to aquatic species and moderately toxic to mammals (PPDB, 2009). Cypermethrin is used in the control of sea lice Lepophtheirus salmonis ectoparasite of Atlantic salmon with efficacy greater than 90\% [51]. This pesticide may have acaricidal action on the control of Rhipicephalus microplus ticks in cattle herds [52]. Its use may also be associated with chlorpyrifos [26], ethion or dichlorvos [25] for the control of ticks. In rainbow trout, cypermethrin has been described as responsible for causing loss of buoyancy, damage to gills and liver cells [53].

Other detected pyrethroids were deltamethrin but only occurred in farm A (2014), in one sample (3.12\%), in the dry season, in the affluent (A1). According to PPDB (2009), it is a semi-volatile insecticide, which belongs to Class II (moderately dangerous), has low aqueous solubility, low leaching potential and is highly toxic to mammals, fish and aquatic invertebrates, but not toxic to birds, oligochaetes and presents risk for bees. This pesticide can be used by means of therapeutic baths in salmon culture to combat all phases of sea lice [54] and may be used to treat cattle to control ticks [25]. In addition to the known inhibition of the AChE enzyme, fish poisoning by deltamethrin can lead to liver and kidney enzyme disorders with increases in the enzyme alkaline phosphatase (ALP) and a decrease in the acid phosphatase (ACP) enzyme, besides adverse effects on hormones, especially cortisol and prolactin [55]. Deltamethrin intoxication may produce genotoxic effects on rainbow trout because they can alter the gene sequence acting on gene expression [31]. The use of cypermethrin and deltamethrin has been shown to have adverse effects on the development, behavior and mortality of different animal species, such as birds, amphibians, aquatic mammals and fish [23].

In water samples collected from the two farms in 2014, fungicide residues of two chemical groups (anilinopyrimidines and strobirulins) were detected, but in 2015 no residue was detected. The chemical group anilinopyrimidine was detected in the two farms, with cyprodinil active principle. The fungicides of the anilinopyrimidine group are applied in agriculture for the control of phytopathogens. Their residues can be detected in the environment with the ability to bioaccumulation in water, sediment and aquatic organisms [2], being toxic to invertebrates, fish, crabs and aquatic macrophytes [2]. Cyprodinil was found in two samples (6.25\%) in farm A (2014), in the rainy season, downstream (A6). In the farm B (year 2014) was also detected in two samples (6.25\%) in the rainy season, but one sample (3.12\%) was detected in the affluent (B1) and another one in the downstream (B9).

Cyprodinil has a systemic action, belongs to Class III (slightly dangerous), has low aqueous solubility, is volatile and presents moderate persistence in water (PPDB, 2009). It has a foliar application in potatoes, onions, apples and tomatoes. Cyprodinil has broad spectrum action with high efficiency against the gray fungus Botrytis cinerea, which attacks grapes and other fruits [56]. The other chemical group, strobirulins were detected, with active principle Trifloxystrobin. Strobirulins are fungicides that can be used alone or applied with other active ingredients (Trifloxystrobin and tebuconazole). They are used in the cultivation of rice and its residues, after draining the fields, may represent a risk of environmental contamination, being toxic to aquatic organisms [57]. Trifloxystrobin was only found in farm A in one sample (3.12\%) downstream (A6) in the rainy season in 2014. Trifloxystrobin belongs to Class $U$ (not likely to present acute hazard), is volatile, has low solubility and susceptible to hydrolysis in 40 days (PPDB, 2009). This fungicide, besides being applied to rice crops [57], is also used in planting corn, soybeans and tomatoes.

The Trifloxystrobin have a superficial and translaminar action, being applied in foliar tissue with curative, eradicating or antisporulating effect against pathogenic fungi [58]. Trifloxystrobin is toxic to several aquatic organisms, such as fish, mainly in the early stages of development, as well as to embryos of the Chinese rare minnow Gobiocypris rarus, where it has caused an increase in the number of malformations due to DNA damage [59] and for the medaka species Oryzias latipes can decrease the incubation capacity, increase mortality in the larval stage and cause lesions 
in the embryos. In addition, it can act as an endocrine disruptor by promoting changes in the expression of the sex hormone of this species [60]. A type of acaricidal compound of the chemical alkyl sulphite group, propargite, was detected in two farms in one sample (3.12\%), downstream (A6 and B9), rainy period in 2014. Compounds of the alkyl sulfite group have broad spectrum contact action, are inhibitors of oxidative phosphorylation and affect ATP formation [61]. They are used to combat mites from cotton, coffee, citrus, and apple and strawberry crops.

According to PPDB (2009), the propargite acaricide is nonsystemic, belongs to Class III (slightly dangerous), and is volatile, with low aqueous solubility. Applied in the cultivation of citrus and ornamental plants to control phytophagous mites. Its residues can contaminate water due to agricultural runoff [62], but in the aquatic environment, hydrolysis is around 13 days. It has high potential for bioconcentration and high toxicity for mammals and fish (PPDB, 2009). The propargite is considered an inhibitor of the cellular respiration of mites, in addition, it has ovicide, larvicide and adulticide action to combat mites Tetranychus urticae, Brevipalpus phoenicis, Tetranychus ulmi [63]. It may present bioaccumulation potential in fish, since it was found in the viscera and "curimatãpioa" muscle (P. costatus) [12].

\section{Toxicological Analyzes on Rainbow Trout (Gills, Liver and Muscle)}

In fish, the accumulation region/organ can vary according to the route of absorption. The pesticide concentration in the organs is determined by the level of contamination of water, food and elements accumulated in the sediment [9]. However, the concentration of pesticides can also occur in the organs such as gills, liver and muscle that were investigated in the present study and of the thirty-six samples of rainbow trout collected during the years 2014 and 2015, in the farm A, no residues were found of any type of the pesticides researched. However, in the farm B, thirtysix samples were also collected and residues of the bifenthrin, furatiocarb and desmedipham pesticides were identified in ten (27.7\%) samples in October 2014, but in the studied samples (gills, liver and muscle) all residual concentrations found were within the detection limit of the equipment.

Residues of the bifenthrin pyrethroids insecticide were detected but not quantified in three samples (30\%) of muscle and one sample of liver (10\%). The bifenthrin has an insecticidal action, is considered a Class II pesticide (moderately dangerous), has agricultural use to control pests that attack leaves (ants) and domissanitary (ticks and fleas), is volatile but has low aqueous solubility (PPDB, 2009). Bifenthrin can contaminate water, sediment and have a toxic action on benthic organisms and fish, in addition to fish, can be absorbed through the gills or bioconcentrate in tissues [2]; Akan et al.[24], Because it is a lipophilic insecticide [24]. It may also generate the 4-hydroxy bifenthrin metabolite that has estrogenic activity in fish [64] and it has been shown that this pyrethroids causes damage on behavior and reproduction in $O$. mykiss [65].
Residues of the herbicide carbamate desmedipham were detected in two samples (6.25\%) in the gills. Desmedipham belongs to Class $\mathrm{U}$, is semi-volatile with low solubility and is not persistent hydrolysis (1 day) (PPDB, 2009). It has agricultural use, being applied in seeds (rice, beans, cotton and corn) and for the control of larvae in the soil. According to Lazhar et al. [66], carbamate herbicide residues can contaminate aquatic ecosystems, causing toxicity to fish that may exhibit deformities and mortality in the early stages of development (embryos and larvae). Residues of carbamate furatiocarb were detected in one sample (3.12\%) of

Muscle, four samples (12.5\%) in the gills and one sample $(3.12 \%)$ in the liver. The insecticide furatiocarb belongs to Class Ib, has low solubility, and is volatile, but very persistent to the hydrolysis process $(11,500$ days). This insecticide can be applied to kill insects that inhabit the soil (PPDB, 2009). Furatiocarb can be genotoxic by inducing mutations and may cause conversion of mitotic genes with increased mitotic chromosomal loss in Saccharomyces cerevisiae [67] strains and is also considered neurotoxin and endocrine disrupting PPDB, [68]. Through the biotransformation process they produce the metabolites carbofuran, 3- hydroxycarbofuran and 3-ketocarbofuran in biological tissues such as liver and kidney [69-73].

\section{Conclusion}

Despite the variety of pesticides found in water in the rainy and dry periods, only two types were quantified (chlorpyrifos and dichlorvos), which may demonstrate a source of contamination through leaching or surface runoff due to the rainy season. The physicochemical parameters evaluated may have contributed to the degradation of pesticides in the water. In both fish farms, A and $B$, no bioconcentration occurred in the rainbow trout tissues of the same residues detected in the water, probably due to the dilution of the compounds in the medium or by the detoxification capacity of the animals. However, it is considered that many pesticides may be more concentrated in the tissues than in the water, a fact that may have occurred for some samples from the month of October of the farm B, where residues of bifenthrin, desmedipham and furatiocarb were identified within the limit (1-10 ppb), suggesting that further studies should be performed due to the possibility of bioconcentration in the aquatic biota.

\section{References}

1. Chowdhury $\mathrm{Az}$, banik $\mathrm{S}$, Uddin $\mathrm{B}$, Moniruzzaman $\mathrm{M}$, karim $\mathrm{N}$, et al. (2012) Organophosphorus and carbamate pesticide residues detected in water samples collected from paddy and vegetable fields of the savar and dhamrai upazilas in bangladesh. Int J Environ Res Publ Health 9: 3318-3329.

2. Smalling kl, kuivila kM, Orlando JL, Phillips BM, Anderson BS, et al. (2013) Environmental fate of fungicides and other current-use pesticides in a central california estuary. Mar Pollut Bul 73(1): 144-153.

3. Ara AG, haque $W$, Hasanuzzaman M (2014) Detection of organochlorine and organophosphorus pesticides residues in water samples of taragong thana in rangpur district in bangladesh. Res J Environ Earth sci 6(2): 8589.

4. Mahboob S, Niazi F, Alghanim K, Sultana S, Al-Misned F, et al. (2015) Health risks associated with pesticide residues in water, sediments and 
the muscle tissues of catla catla at head balloki on the river ravi Environ monit. Assess 187(3): 81.

5. Hui TO, Ariffin MM, Tahir NM (2010) Hydrolysis of chlorpyrifos in aqueous solutions at different temperatures and $\mathrm{pH}$. Malaysian $\mathrm{j}$ Anal Sci 14(2): 50-55.

6. Cieslik LF, Vidal RA, Trezzi MM (2013) Fatores ambientais que afetam a eficácia de herbicidas inibidores da accase: revisão. Planta daninha 31(2): 483-489.

7. Barret k, Jaward FM (2012) A review of endosulfan, dichlorvos, diazinon, and diuron - pesticides used in Jamaica. Int J Environ Health res 22(6): 481-499.

8. Altinok I, Capkin E, Karahan S, Boran M (2006) Effects of water quality and fish size on toxicity of methiocarb, a carbamate pesticide, to rainbow trout. Environ Toxicol Pharmacol 22(1): 20-26.

9. Essumang DK, Tagoh GK, Chokky L (2009) Pesticide residues in the water and fish (lagoon tilapia) samples from lagoons in ghana Bull Chem Soc Ethiopia 23(1): 19-27.

10. Greco l, Serrano R, Blanes MA, Serrano E (2010) capri e bioaccumulation markers and biochemical responses in european sea bass (dicentrarchus labrax) raised under different environmental conditions. Ecotoxicol Environ Saf 73: 38-45.

11. Akan JC, Sodipo OA, Mohammed Z (2014) Abdulrahman fi determination of organochlorine, organophosphorus and pyrethroid pesticide residues in water and sediment samples by high performance liquid chromatography (hplc) with uv/visible detector. J Anal Bioanal Tech 5: 6

12. Oliveira FA, Reis LPG, Soto-Blanco B, Melo MM (2015) Pesticides residues in the prochilodus costatus (valenciennes, 1850) fish caugth in the são francisco river brazil. J Environ Sci Health B 50(6): 398-405.

13. Bondarenko S, Gan J, Harver DL, Kabashima JN (2004) Persistence of selected organophosphate and carbamates insecticides in water from a coastal watershed Environ. Toxicol Chem 23(11): 2649-2654.

14. Faria SR, Moreira SE, Gusmão CRS, Alkmin EG (2014) Delfim Moreira, Seu Tempo, Sua História Disponível.

15. (2008) APHA- American public health association Standard methods for examination of water and wastewater, USA.

16. Luke MA, Froberg JE, Masumoto HT (1975) Extraction and cleanup of organochlorine, organophosphate, organonitrogen and hydrocarbon pesticides in produce for determination by gas-liquid chromatography. Journal of the association of official analitycal chemists 58(5): 10201026 .

17. Anastassiades M, lehotay S, Stajnbaher D, Schenck FJ (2003) Fast and easy multiresidue method employing acetonitrile extraction/ partitioning and dispersive solid-phase extraction for the determination of pesticide residues in produce. J Aoac int 86(2): 412-431.

18. Zamy C, Mazellier P, Legube B (2004) Analytical and kinetic study of the aqueous hydrolysis of four organophosphorus and two carbamate pesticides. Intern J environ Anal Chem 84(14-15): 1059-1068.

19. Jilani S (2008) The influence of dissolved oxygen on growth and degradation of cypermethrin by pseudomonas using a biosimulator. Wit Trans Ecol Environ 111: 501-510.

20. Lartiges SB, Garrigues PP (1995) Degradation kinetics of organophosphorus and organonitrogen pesticides in different waters under various environmental conditions. Environ Sci Technol 29(5): 1246-1254.

21. Veiga MM,Silva DM, Veiga LBE, Faria MVC (2006) Análise da contaminação dos sistemas hídricos por agrotóxicos numa pequena comunidade rural do sudeste do brasil. Cad Saúde pública 22: 2391-2399.

22. Arjmandi R, Tavakol M, Shayeghi M (2010) Determination of organophosphorus insecticides residues in the rice paddies. Int J Environ Sci Tech 7(1): 75-182.
23. Ali SFM, Shieh BHH, Alehaideb Z, Khan MZ, Louie A, et al. (2011) A review on the effects of some selected pyrethroids and related agrochemicals on aquatic vertebrate biodiversity Can. J Pur Appl Sci 5(2): 1455-1464.

24. Akan JC, Abdulrahman FI, Chellube ZM (2014) Organochlorine and organophosphorus pesticide residues in fish samples from lake chad, baga, north eastern Nigeria. Int J Innov Manag Technol 5: 2.

25. Neto SFP, Toledo-Pinto EA (2006) Análise da eficiência de carrapaticidas contra boophilus microplus em gado leiteiro. Rev Cient Eletrônica med Vet 3: 1-7.

26. Heidmann MJ, Souza AAD, Nascimento CG, Bragaglia GN, Lima LMS, et al. (2016) Eficácia acaricida da associação de cipermetrina, fenthion e clorpirifós em bovines naturalmente infestados por rhipicephalus microplus na amazônia matogrossense. Vet Zootec 23: 4.

27. Chaparro J, Taborda DAA, Urrea L, Rodríguez BJ (2013) Liver immunolocation of cyp p450 in an subacute toxicity experiment with clorpirifos o,o-(3, 5, 6- trichloride -2-pyridyl phosphorotioato) in young male tilapia (oreochromis spp) Ces med Zootec 8(2): 61-72.

28. Srivastav AK, Srivastava SK, Sarojni Tripathi S, Mishra D (2012) Morphotoxicology of chlorpyrifos to prolactin cells of a freshwater catfish, heteropneustes fossilis. Acta sci Biol Sci 34(4): 443-449.

29. Atamanalp M, Angis S, Oguzhan P, Aksakal E (2008) Alterations in hematological parameters of rainbow trout (oncorhynchus mykiss) exposed to DDVP Isr. J Aquacult 60(1): 9-12.

30. Das S (2013) A review of dichlorvos toxicity in fish. Curr World environ 8(1): 143- 149.

31. Atamanalp M, Erdoğan O (2010) Alterations of hsp70 gene expression in rainbow trout (oncorhyncus mykiss) exposed to deltamethrin. Turk J Vet Anim Sci 34(4): 359-363.

32. Günde EG, Yerli SV (2012) the comparative study on the acute toxicity of dichlorvos on guppy (poecilia reticulata $p, 1859$ ) and carp (cyprinus carpio l, 1758). hacettepe j Biol Chem 40(2): 165-170.

33. Bhat BA, Bhat IA, Vishwakarma S, Verma A, Saxena GA (2012) comparative study on the toxicity of a synthetic pesticide, dichlorvos and a neem based pesticide, neem-on to labeo rohita (hamilton). Curr World Environ 7(1): 157-161.

34. Banaee M, Sureda A, Mirvaghefi AR, Ahmadi K (2013) Biochemical and histological changes in the liver tissue of rainbow trout (oncorhynchus mykiss) exposed to sub-lethal concentrations of diazinon Fish. physiol Biochem 39(3): 489-501.

35. Cong NV, Phuong NT, Bayley M (2009) Effect of repeated exposure of diazinon of cholinesterase activity and growth in snakehead fish (channa striata). Ecotoxicol Environ Saf 72(3): 699-703.

36. Nwani CD, Okeke OC, Onyishi G, Chinedu Atama C, Uzoma Chinekwu, et al. (2012) Toxicity and effects of diazinon on behaviour and some haematological parameters of african catfish clarias gariepinus. Zool Ecol 23: 45-52.

37. Bhatti GK, Kiran R, Sandhir R (2010) Modulation of ethion-induced hepatotoxicity and oxidative stress by vitamin e supplementation in male wistar rats Pestic. Biochem Physiol 98: 26-32.

38. Chetan PS, Kumar RR, Mohan PM (2009) Phosalone induced changes in regional cholinesterase activities in rat brain during behavioral tolerance. Afr Res Rev 3(2): 20-30.

39. Kaya H, Çelik ES, Gürkan M, Yilmaz S, Akbulut M (2013) Effects of subchronic exposure to phosalone on oxidative stress and histopathological alterations in common carp (cyprinus carpio, 1, 1758). J Toxicol Environ Health A 76(14): 853-864.

40. Santos FF, Rezende MOO (2002) Influência do meio reacional no comportamento fotoquímico do inseticida paration. etílico Quim Nova 25(1): 53-58.

41. Anogwih JA (2014) Toxicity of pirimiphos methyl (actellic 25ec) on anopheles gambiae ss, culex quinquefasciatus (diptera: culicidae), and 
potential biocontrol agent, poecilia reticulata (pisces: poeciliidae). J Econ Entomol 107(4): 1440-1446.

42. Montuori PS, Garzonio F, Sarnacchiaro P, Polichetti S, Nardone A, et al (2016) Estimates of tiber river organophosphate pesticide loads to the tyrrhenian sea and ecological risk Sci total environ 559: 218-231.

43. Lawal MO, Samuel OB (2010) Investigação de toxicidade aguda de pirimiphos- metilo (actellic $^{\circledR}, 25 \%$ ec) em guppy (poecilia reticulata, peters, 1859). Pak J Biol Sci 13(8): 405-408.

44. Wang J, Grisle S, Schlenk D (2001) Effects of salinity on aldicarb toxicity in juvenile rainbow trout (oncorhynchus mykiss) and striped bass (morone saxatilis x chrysops). Toxicol Sci 64(2): 200-207.

45. Karayalanoglu T, Tenar L, Serdar M, Kose S, Aydin A (2008) Bacterial biodegradation of aldicarb and determination of bacterium which has the most biodegradative effect. Turk J Biochem 33(4): 209-214.

46. Ferrari A, Venturino AD, Anglo AM (2007) Effects of carbaryl and azinphos methyl on juvenile rainbow trout (onchorhyncus mykiss) detoxifying enzymes. Pestic Biochem Physiol 88: 134-142.

47. Begum G (2011) Organ-specific atpase and phosphorylase enzyme activities in a food fish exposed to a carbamate insecticide and recovery response. Fish physiol Biochem 37(1): 37-61.

48. Ramesh M, Narmadha S, Poopal RK (2015) Toxicity of furadan (carbofuran $3 \% \mathrm{~g}$ ) in cyprinus carpio: haematological, biochemical and enzymological alterations and recovery response Beni-seuf univ. J Appl Sci 4: 314-326.

49. Soderlund DM, Clark JM, Sheets LP, Mullin LS, Piccirillo VJ, et al. (2002) Mechanisms of pyrethroid neurotoxicity: implications for cumulative risk assessment. Toxicology 171(1): 3-59.

50. Jimenez DF, Revie CW, Hardy SP, Jansen PA, Gettinby G (2013) Multivariate evaluation of the effectiveness of treatment efficacy of cypermethrin against sea lice (lepeophtheirus salmonis) in atlantic salmon (salmo salar). Vet Res 9: 9-19.

51. Carneiro JC, Costa EGL, Vasconcelos VO, Oliveira NJF, Duarte ER (2015) Diagnóstico do controle e eficácia de acaricidas para o carrapato bovino no semiárido do norte de minas gerais. Acta sci Vet 43: 1-10.

52. Velisek J, Wlasow T, Gomulka P, Svobodova Z, Dobsikova R, et al. (2006) Effects of cypermethrin on rainbow trout (oncorhynchus mykiss). Vet Med 51(10): 469-476.

53. Burridge L, Weis JW, Cabello F, Pizarro J, Bostickles K (2010) Chemical use in salmon aquaculture: a review of current practices and possible environmental effects. Aquaculture 306: 7-23.

54. Suvetha L, Saravanan M, Hur JH, Ramesh M, Krishnapriya K (2015) Acute and sublethal intoxication of deltamethrin in an indian major carp, labeo rohita: hormonal and enzymological responses. J Basic Appl Zool 72: 5875.

55. Fritz R, Lanen C, Chapeland-Leclerc F, Leroux P (2003) Effect of the anilinopyrimidine fungicide pyrimethanil on the cystathionine b-lyase of botrytis cinerea Pestic. Biochem Physiol 77: 54-65.

56. Cao M, Li S, Wang Q, Wei P, Liu Y, et al. (2015) Track of fate and primary metabolism of trifloxystrobin in rice paddy ecosystem. Sci Total environs 518-519: 417-423.

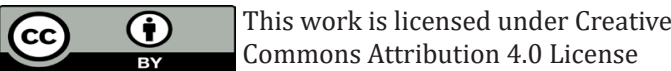

Submission Link: https://biomedres.us/submit-manuscript.php
57. Balba H (2007) Review of strobilurin fungicide chemicals. J Environ Sci Health B 42(4): 441-451.

58. Zhu B, Liu GL, Liu L, Ling F, Wang GX (2015) Assessment of trifloxiystrobin uptake kinetics, developmental toxicity and mrna expression in rare minnow embryos. Chemosphere 120: 447-455.

59. Zhu L, Wang H, Liu H, Li W (2013) Effect of trifloxystrobin on hatching, survival, and gene expression of endocrine biomarkers in early life stages of medaka (oryzias latipes). Environ Toxicol 30(6): 648-655.

60. Sato M (2017) Manejo da resistência de ácaro rajado em culturas Irac br p. 2.

61. Sabale SR, Tamhankar BV, Dongare MM, Mohite BS (2012) Extraction determination and bioremediation of heavy metal ions and pesticide residues from lake water. J Bioremed Biodeg 3(4): 143-165.

62. Franco CR, Casarin NFB, Domingues FA, Omoto C (2007) Resistência de brevipalpus phoenicis (geijskes) (acari: tenuipalpidae) a acaricidas inibidores da respiração celular em citros: resistência cruzada e custo adaptativo. Neotrop Entomol 36: 565-576.

63. Degroot BC, Brander SM (2014) the role of p450 metabolism in the estrogenic activity of bifenthrin in fish. Aquat Toxicol 156: 17-20.

64. Crago J, Schlenk D (2015) The effect of bifenthrin on the dopaminergic pathway in juvenile rainbow trout (oncorhynchus mykiss). Aquat Toxicol 162: 66-72

65. Lazhar M, Hela T, Moncef B, Néji A (2012) Toxicity of three selected pesticides (alachlor, atrazine and diuron) to the marine fish (turbot psetta maxima). Afr J biotechnol 11(51): 11321-11328.

66. Stehrer Schmid P, Wolf HU (1995) Genotoxic evaluation of three heterocyclic $n$ - methylcarbamate pesticides using the mouse bone marrow micronucleus assay and saccharomyces cerevisiae strain D7 and D61 m. Mutat Res 345: 111-125.

67. PPDB - pesticide properties database the pesticide properties database (PPDB) developed by the agriculture \& environment research unit (aeru), university of hertfordshire, funded by uk national sources and the eu-funded footprint, UK.

68. Liu KH, Sung HJ, Lee HK, Song BH, Ihm YB, et al. (2001) dermal pharmacokinetics of the insecticide furathiocarb in rats. Pestmanag Sci 58(1): 57-62.

69. (2010) Agência nacional de vigilância sanitária-anvisa Monografias de agrotóxicos Disponível, Brasil.

70. (2016) Codex alimentarius Pesticide residues in food: maximum residue limits, extraneous maximum residue limits Roma.

71. EC (European commission) Directorate general for health \& consumers Pesticides.

72. Demoute JP (1989) A brief review of the environmental fate and metabolism of pyrethroids. Pest sci 27: 375-385.

73. Footprint (2011) Creating tools for pesticide risk assessment and management in Europe.

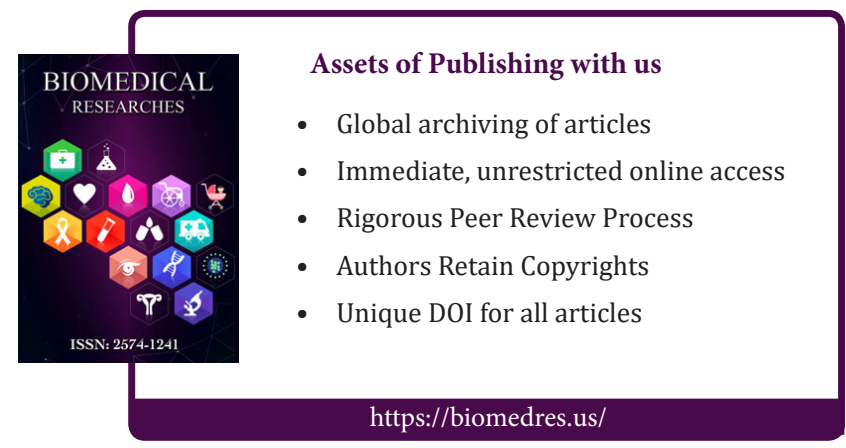

